\title{
Genistein Inhibits Expressions of NADPH Oxidase p22phox and Angiotensin II Type 1 Receptor in Aortic Endothelial Cells from Stroke-Prone Spontaneously Hypertensive Rats
}

\author{
Jin-Wen $\mathrm{XU}^{*},{ }^{* *}$, Katsumi IKEDA ${ }^{*},{ }^{* *}$, and Yukio YAMORI ${ }^{* * *}$
}

\begin{abstract}
Phytoestrogens are considered to be natural selective estrogen receptor modulators exerting antioxidant activity and improving vascular function. However, the mechanisms responsible for their antioxidative effects remain largely unknown. This study tested the hypothesis that genistein may provide significant endothelial protection by antioxidative effects through attenuating NADPH oxidase expression and activity. The results showed that genistein suppressed the expressions of the p22phox NADPH oxidase subunit and angiotensin II (Ang II) type 1 (AT1) receptor in a concentration- and time-dependent manner in aortic endothelial cells from stroke-prone spontaneously hypertensive rats examined by Western blot analysis. Treatment with genistein also remarkably reduced the Ang Il-induced superoxide by the reduction of nitroblue tetrazolium, inhibited nitrotyrosine formation, and attenuated endothelin-1 production by ELISA via the stimulation of Ang II. However, when cells were pretreated with ICl-182780, an estrogen-receptor antagonist, at a concentration of $50 \mu \mathrm{mol} / \mathrm{l}$ for $30 \mathrm{~min}$ and then co-incubated with ICl-182780 and genistein for $24 \mathrm{~h}$, the inhibitory effect of genistein was not blocked. In contrast, the inhibitory effect of genistein treatment was partially reversed by 30-min pretreatment of endothelial cells with GW9662, a peroxisome proliferator-activated receptor $Y$ (PPARY) antagonist. Genistein thus appears to act as an antioxidant at the transcription level by the downregulation of p22phox and AT1 receptor expression. Our data also showed that the PPARY pathway was involved, at least in part, in the inhibitory effect of genistein on the expression of p22phox and AT1 receptors. The endothelial-protective effects of phytoestrogen may contribute to improvement of cardiovascular functions. (Hypertens Res 2004; 27: 675-683)
\end{abstract}

Key Words: phytoestrogen, NADPH oxidase p22phox subunit, angiotensin II type 1 receptor, endothelium, peroxisome proliferator-activated receptor $Y$

\section{Introduction}

Many studies have provided a wide range of experimental evidence indicating that angiotensin II (Ang II) promotes the production of free radicals in the pathogenesis of cardiovascular disease. Increased expression of NADPH oxidase sub- units has been shown to play a role in the formation of human atherosclerotic lesions and in animal models of hypertension and atherosclerosis (1-6). In vascular endothelial cells, Ang II also induces superoxide anion generation via the activation of NADPH oxidase (7), which mediates endothelial dysfunction and peroxynitrite formation (8). The p22phox subunit is an essential protein in the activation of

From the ${ }^{*}$ Frontier Health Science, School of Human Environmental Science and ${ }^{* *}$ Research Center for Life-Style Related Diseases, Mukogawa Women's University, Nishinomiya, Japan, and ${ }^{* * *}$ WHO Collaborating Center for Research on Primary Prevention of Cardiovascular Diseases, Kyoto, Japan.

Address for Reprints: Jin-Wen Xu, M.D., Ph.D., School of Human Environmental Science, Mukogawa Women's University, 9-11-68 Koshi-en, Nishinomiya 663-8179, Japan. E-mail: jwxu@mwu.mukogawa-u.ac.jp

Received March 3, 2004; Accepted in revised form May 13, 2004. 
NADPH oxidase, since stroke-prone spontaneously hypertensive rats (SHRSP), but not Wistar-Kyoto rats, display the oxidative inactivation of nitric oxide and endothelial dysfunction (9). Recently, some studies have indicated that, after exposure to Ang II, the elevation of superoxide production occurs through the Ang II type 1 (AT1) receptor activation of NADPH oxidase in the coronary arterioles, renal cortices, and human umbilical vein endothelial cells (HUVECs) (10-12).

Epidemiological and experimental studies have generally shown that phytoestrogens play an important role in the prevention of cardiovascular disease (13-16). Phytoestrogens stimulate the activity of estrogen receptors, such as genistein, that strongly bind to estrogen receptor subtype $\beta$, and phytoestrogens are approximately one-third as potent as $17 \beta$ estradiol $(17,18)$. Moreover, phytoestrogens have been shown to possess antioxidant activity $(19,20)$. Many studies have found that phytoestrogens can function as antioxidants and protect against oxidative DNA damage (21-23). Recently, a single study suggested that phytoestrogens affect expression levels of catalase (24). However, the antioxidant mechanisms of phytoestrogens remain unclear. On the other hand, two recent reports have shown that genistein can act as a peroxisome proriferator-activated receptor $\gamma(\operatorname{PPAR} \gamma)$ agonist to improve the lipid metabolism in RAW 264.7 cells from obese Zucker rats (25) and in mesenchymal progenitor cells (26). In the present study, we tested the hypothesis that genistein may modulate NADPH oxidase expression and activity, and that such mediation, if present, may occur at least in part via the PPAR $\gamma$ pathway. For this purpose, we observed the antioxidant effect of genistein in vascular endothelial cells isolated from SHRSP. Our results showed that treatment with genistein reduced superoxide anions, inhibited nitrotyrosine production, and suppressed the expressions of the p22phox NADPH oxidase subunit and AT1 receptor. These inhibitory effects of genistein were reversed by GW9662, an antagonist of PPAR $\gamma$, but were not blocked by the estrogen receptor antagonist, ICI-182780, suggesting that genistein functions as a nuclear receptor agonist independent of the estrogen receptor, and that the actions of genistein involve, at least in part, the $\operatorname{PPAR} \gamma$ signal pathway.

\section{Methods}

\section{Materials}

Ang II was obtained from Sigma (St. Louis, USA). Genistein and nitroblue tetrazolium (NBT) were from Wako Pure Chemicals (Osaka, Japan). ICI-182780 and GW9662 were from Tocris (Ballwin, USA). Acetylated low density lipoprotein labeled with 1,1'-dioctadecyl-3,3,3',3'-tetramethylidocarbocyanine perchlorate (Dil-acetyl-LDL) was purchased from Biomedical Technologies Inc. (Stoughton, USA). AntiNADPH oxidase p22phox subunit, anti-AT1 receptor, and anti- $\beta$-actin were from Santa Cruz Biotechnology Inc. (Santa
Cruz, USA). Anti-rabbit or goat IgG peroxidase-linked species-specific whole antibodies, and the ECL plus Western blotting detection system were obtained from Amersham Corp. (Buckinghamshire, UK). The nitrotyrosine ELISA kit was from Kamiya Biomedical Co. (Seattle, USA). The endothelin EIA immunoassay kit was purchased from Peninsula Laboratories Inc. (San Carlos, USA).

\section{Animals, Isolation of Rat Aortic Endothelial Cells, and Cell Culture}

SHRSP were obtained from the animal unit of the Graduate School of Human and Environmental Studies of Kyoto University.

Vascular endothelial cells were isolated from the rat aorta as previously described (27). Whole rat thoracic aortae were collected from male SHRSP, and washed well with phosphate-buffered saline (PBS). The 16-week-old vessels were cleaned of periadventitial fat and connective tissue and cut into flat pieces of about $4 \mathrm{~mm}^{2}$, placed on rat tail collagen type I-coated dishes (Becton Dickinson Labware, Sunnyvale, USA), and incubated in Dulbecco's modified Eagle's medium (DMEM) supplemented with $10 \%$ fetal bovine serum (FBS), $100 \mathrm{U} / \mathrm{ml}$ of penicillin, and $100 \mu \mathrm{g} / \mathrm{ml}$ of streptomycin in a humidified incubator at $37^{\circ} \mathrm{C}$ and $5 \% \mathrm{CO}_{2}$. After 6 to 9 days, depending on the degree of outgrowth, the aortic explants were removed. At confluence, the cells were detached and re-plated in 100-mm culture plastic dishes. The cells were subcultured for up to 5 to 7 passages, and removed from the culture dishes using $0.05 \%$ trypsin $/ 0.02 \%$ EDTA. The cells were identified by the uptake of fluorescent Dil-acetyl-LDL.

\section{Western Blot Analysis}

Preparation and immunoblot analysis of protein extracts from the cultured SHRSP aortic endothelial cells were performed as described previously (28). The cells were washed twice in PBS and harvested in RIPA's buffer (1\% Nonidet$\mathrm{P} 40,50 \mathrm{mmol} / \mathrm{l}$ of Tris/ $\mathrm{HCl}$ [pH 8.0], $150 \mathrm{mmol} / \mathrm{l}$ of $\mathrm{NaCl}$, $2 \mathrm{mmol} / \mathrm{l}$ of sodium orthovanadate, $1 \%$ sodium deoxycholate, $0.1 \%$ sodium dodecyl sulfate (SDS), $0.1 \mathrm{mmol} / 1$ dithiothreitol, $0.05 \mathrm{mmol} / \mathrm{l}$ phenylmethyl-sulfonylfluoride, $0.002 \mathrm{mg} / \mathrm{ml}$ of aprotinin, $0.002 \mathrm{mg} / \mathrm{ml}$ of leupeptin). Protein concentrations were determined in cell lysates using the Protein DC plus Assay Kit (Bio-Rad Laboratories Inc., Hercules, USA). Bovine serum albumin was used as the standard. Equal amounts of protein were directly solubilized in sample buffer (25\% 0.5 mmol/1 Tris/HCl [pH 6.8], 20\% glycerol, 4\% SDS, $0.005 \%$ bromophenol blue, $5 \%$ 2-mercaptoethanol). Samples were heated for $5 \mathrm{~min}$ at $95^{\circ} \mathrm{C}$, separated by SDS-polyacrylamide gel electrophoresis (PAGE), and transferred to nitrocellulose membranes. The membranes were blocked with 5\% skim milk in Tris-buffered saline-Tween buffer for 30 min, and incubated with the primary antibody for $2 \mathrm{~h}$. Specif- 
ically bound primary antibodies were detected with the peroxidase-coupled second antibody and enhanced with the ECL plus the Western blotting detection system. Quantitative analysis of the band density was performed using $\mathrm{NIH}$ Image 1.63 Software. Western blot experiments were performed in duplicate or triplicate.

\section{Detection of Superoxide by NBT Reduction}

$\mathrm{O}_{2}{ }^{-}$production by endothelial cells was measured using the NBT reduction assay as described by Suh et al. (29) and Wang et al. (30). Approximately $10^{6}$ cells per well were plated and grown for $24 \mathrm{~h}$. After the cells had been treated with genistein for $24 \mathrm{~h}$ or $30 \mathrm{~min}$, the medium was removed and the cells were washed or not washed with $5 \mathrm{ml}$ PBS. Filtered $0.25 \%$ NBT $(5 \mathrm{ml})$ was added and cells were incubated at $37^{\circ} \mathrm{C}$ for $20 \mathrm{~min}$ to allow the superoxide anion to reduce the NBT to blue formazan. The cells were scraped off and formazan was pelleted by centrifugation at $12,000 \times g$ for 30 min. The formazan pellets were suspended in $1 \mathrm{ml}$ of pyridine and heated at $100^{\circ} \mathrm{C}$ for $10 \mathrm{~min}$ to extract formazan. The mixture was subjected to a second centrifugation at $10,000 \times g$ for $10 \mathrm{~min}$. The absorbance of formazan was determined using a spectrophotometer at $510 \mathrm{~nm}$. The extinction coefficient (e) of blue formazan is $26,478(\mathrm{~mol} / \mathrm{l})^{-1} \mathrm{~cm}^{-1}$. The quantity of formazan was calculated as follows: NBT reduction $\left(\mathrm{nmol} / \mathrm{h} \cdot 10^{6}\right.$ cells $)=A \cdot V /(T \cdot e \cdot l)$, where $A$ is the absorbance of blue formazan at $510 \mathrm{~nm}, V$ is the volume $(\mathrm{ml})$ of the solution per $10^{6}$ cells, $T$ is the time period ( $\mathrm{min}$ ) during which cells were incubated with $\mathrm{NBT}, e$ is the extinction coefficient, and $l$ is the length ( $\mathrm{mm}$ ) of the light path.

\section{Analysis of 3-Nitrotyrosine Content in Cultured SHRSP Aortic Endothelial Cells}

After treatment of SHRSP aortic endothelial cells with genistein for $24 \mathrm{~h}$, the medium was removed, the cells were washed with $5 \mathrm{ml} \mathrm{PBS}$, and then the cells were stimulated with $1 \mu \mathrm{g} / \mathrm{ml}$ of Ang II for $2 \mathrm{~h}$ and washed twice with PBS. Protein extractions were performed using ice-cold tissue lysis buffer $(50 \mathrm{mmol} / \mathrm{l}$ of Tris- $\mathrm{HCl}, \mathrm{pH} 7.4,1 \%$ Nonidet-P40, $0.25 \%$ sodium deoxycholate, $150 \mathrm{mmol} / \mathrm{l}$ of $\mathrm{NaCl}, 0.05$ $\mathrm{mmol} / \mathrm{l}$ of phenylmethylsulfonyl fluoride, $1 \mathrm{mg} / \mathrm{ml}$ of aprotinin, $1 \mathrm{mg} / \mathrm{ml}$ of leupeptin, $1 \mathrm{mg} / \mathrm{ml}$ of pepstatin, $1 \mathrm{mmol} / \mathrm{l}$ of $\mathrm{Na}_{3} \mathrm{VO}_{4}$, and $1 \mathrm{mmol} / \mathrm{l}$ of $\mathrm{NaF}$ ). The protein extracts were centrifuged at $10,000 \times g$ for $10 \mathrm{~min}$ at $4^{\circ} \mathrm{C}$, and the supernatants were collected and assayed for protein and nitrotyrosine content. The protein concentrations of the supernatants were determined using a Bio-Rad Protein DC plus Assay Kit. Quantitation of the cellular nitrotyrosine levels was performed by ELISA according to the manufacturer's instructions (Kamiya Biomedical Co.). Data were normalized to the nitrotyrosine content of samples as nmol of nitrotyrosine per milligram of total protein.

\section{Detection of Endothelin-1 Level}

Endothelin-1 levels in media were measured with an ELISA immunoassay kit according to the manufacturer's instructions. In brief, media and the primary antibody as well as the biotinylated peptide solution were dispensed into designated wells of a 96-well immunoplate and incubated for $2 \mathrm{~h}$ at room temperature. After washing 5 times, streptavidinhorseradish peroxidase was added to each well and incubated for $1 \mathrm{~h}$. Finally, the microplate was washed and tetramethylbenzidine solution was added to each well. After $30 \mathrm{~min}$, the reaction was terminated with $\mathrm{HCl}$. The absorbance at $450 \mathrm{~nm}$ was measured within $20 \mathrm{~min}$.

\section{Statistical Analysis}

Data are expressed as the mean \pm SEM. Statistical analysis was performed using an ANOVA test. Values of $p<0.05$ were considered statistically significant.

\section{Results}

\section{Effects of Genistein on $\mathrm{O}_{2}^{-}$Formation and 3-N-Nitroty- rosine Production in Ang II-Stimulated SHRSP Arterial Endothelial Cells}

To identify the antioxidative function of genistein, we first examined its inhibitory effect on Ang II-induced $\mathrm{O}_{2}{ }^{-}$anion formation as assessed by the reduction of NBT. Stimulation with Ang II $(1 \mu \mathrm{g} / \mathrm{ml})$ resulted in increased $\mathrm{O}_{2}{ }^{-}$formation

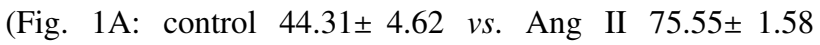
$\mathrm{nmol} / \mathrm{h} \cdot 10^{6}$ cells; Fig. 1B: control $34.72 \pm 1.16 v s$. Ang II $44.81 \pm 2.59 \mathrm{nmol} / \mathrm{h} \cdot 10^{6}$ cells; each $\left.n=3, p<0.05\right)$, whereas after pre-incubation with genistein $(50 \mu \mathrm{mol} / \mathrm{l})$ for $24 \mathrm{~h}$ and only a single washing with PBS, the Ang II-stimulated $\mathrm{O}_{2}{ }^{-}$ formation diminished to $29.36 \pm 0.64 \mathrm{nmol} / \mathrm{h} \cdot 10^{6}$ cells in the SHRSP arterial endothelial cells, as shown in Fig. 1B $(n=3$, $p<0.05$ vs. Ang II). In contrast, after treatment with genistein for $30 \mathrm{~min}$ and washing once, the Ang II-stimulated $\mathrm{O}_{2}{ }^{-}$formation was not been reduced, as shown in Fig. 1A.

Endothelial dysfunction has been shown to occur in SHRSP (8), and protein nitration has been shown to occur in Ang II-induced cardiovascular tissues (9). To confirm the preventive role of genistein and antioxidants on protein nitration, we detected $N$-nitrotyrosine formation in Ang IIstimulated SHRSP artery endothelial cells. After Ang II stimulation at $1 \mu \mathrm{g} / \mathrm{ml}$ for $2 \mathrm{~h}$, the level of $N$-nitrotyrosine was $138.90 \pm 12.34(\mathrm{ng} / \mathrm{mg}$ protein), but after pretreatment with genistein for $24 \mathrm{~h}$ and washing once with PBS, the formation of $N$-nitrotyrosine decreased to $104.85 \pm 5.32$ (genistein at $50 \mu \mathrm{mol} / \mathrm{l}, \mathrm{ng} / \mathrm{mg}$ protein), as shown in Fig. $1 \mathrm{C}(n=6$, $p<0.05)$. 

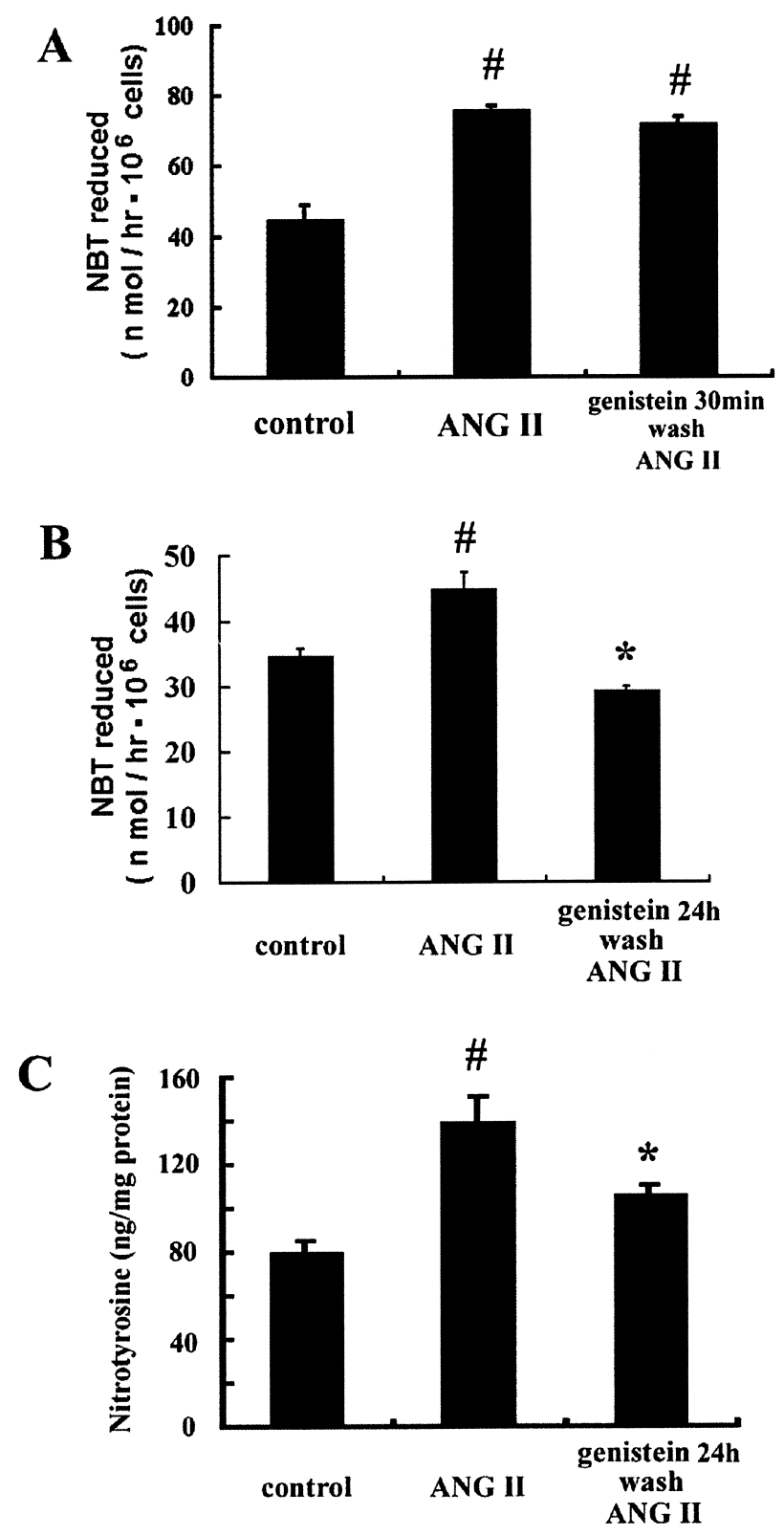

Fig. 1. Inhibitory effect of genistein on superoxide anion (A and $B$ ) and nitrotyrosine $(C)$ generation in Ang II-stimulated vascular endothelial cells from SHRSP. Reduction of nitroblue tetrazolium (NBT) and nitrotyrosine in endothelial cells from SHRSP was measured in the presence or absence of genistein. After the cells had been incubated with genistein at $50 \mu \mathrm{mol} / \mathrm{l}$ for $30 \mathrm{~min}(A)$ or $24 \mathrm{~h}(B)$, they were stimulated with Ang II at $1 \mu \mathrm{g} / \mathrm{ml}$ at $37^{\circ} \mathrm{C}$ for $20 \mathrm{~min}$ (for $\mathrm{NBT}$ reduction) or for $3 \mathrm{~h}$ (for nitrotyrosine). Results are the mean \pm SEM from 3 or 4 independent wells. ${ }^{\#} \mathrm{p}<0.05$ vs. control groups, ${ }^{*} \mathrm{p}<0.05$ vs. Ang II treatment groups.
A
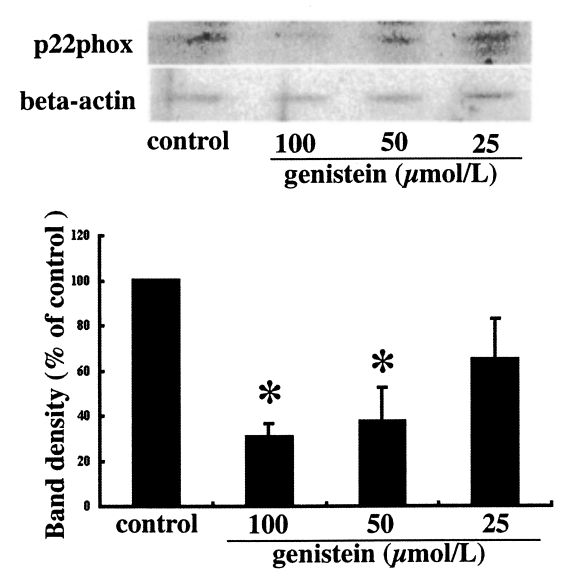

B
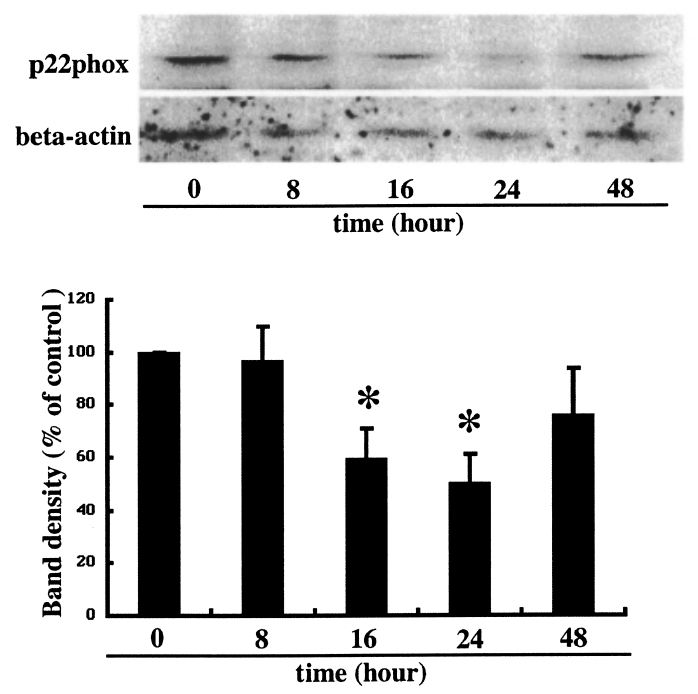

Fig. 2. Inhibitory effect of genistein on the expression of NADPH oxidase p22phox subunits in vascular endothelial cells from SHRSP by Western blotting assay. The cells were treated with genistein at 100, 50, or $25 \mu \mathrm{mol} / \mathrm{l}$ for $24 \mathrm{~h}(\mathrm{~A})$, or treated with genistein at $50 \mu \mathrm{mol} / \mathrm{l}$ for $8,16,24$, or $48 \mathrm{~h}(B)$. The relative intensities compared with the control are shown as the mean \pm SEM of 3 independent experiments. ${ }^{*} \mathrm{p}<0.05$ vs. control.

Inhibitory Effect of Genistein on Expressions of p22phox NADPH Oxidase Subunit and AT1 Receptor in SHRSP Arterial Endothelial Cells

Next, we investigated the effect of genistein on the expressions of the p22phox NADPH oxidase subunit and AT1 receptor in SHRSP arterial endothelial cells. Treatment with genistein at 100,50 , or $25 \mu \mathrm{mol} / 1$ for $24 \mathrm{~h}$ repressed the expression of p22phox NADPH oxidase subunits (Fig. 2A) in a concentration-dependent manner, in addition to inhibiting the AT1 receptor (Fig. 3A). Treatment with genistein at 100, 50 , or $25 \mu \mathrm{mol} / 1$ significantly repressed $\mathrm{p} 22$ phox expression to roughly $30.7 \pm 5.7 \%, 37.4 \pm 15.1 \%$, or $64.9 \pm 18.0 \%$ of the 

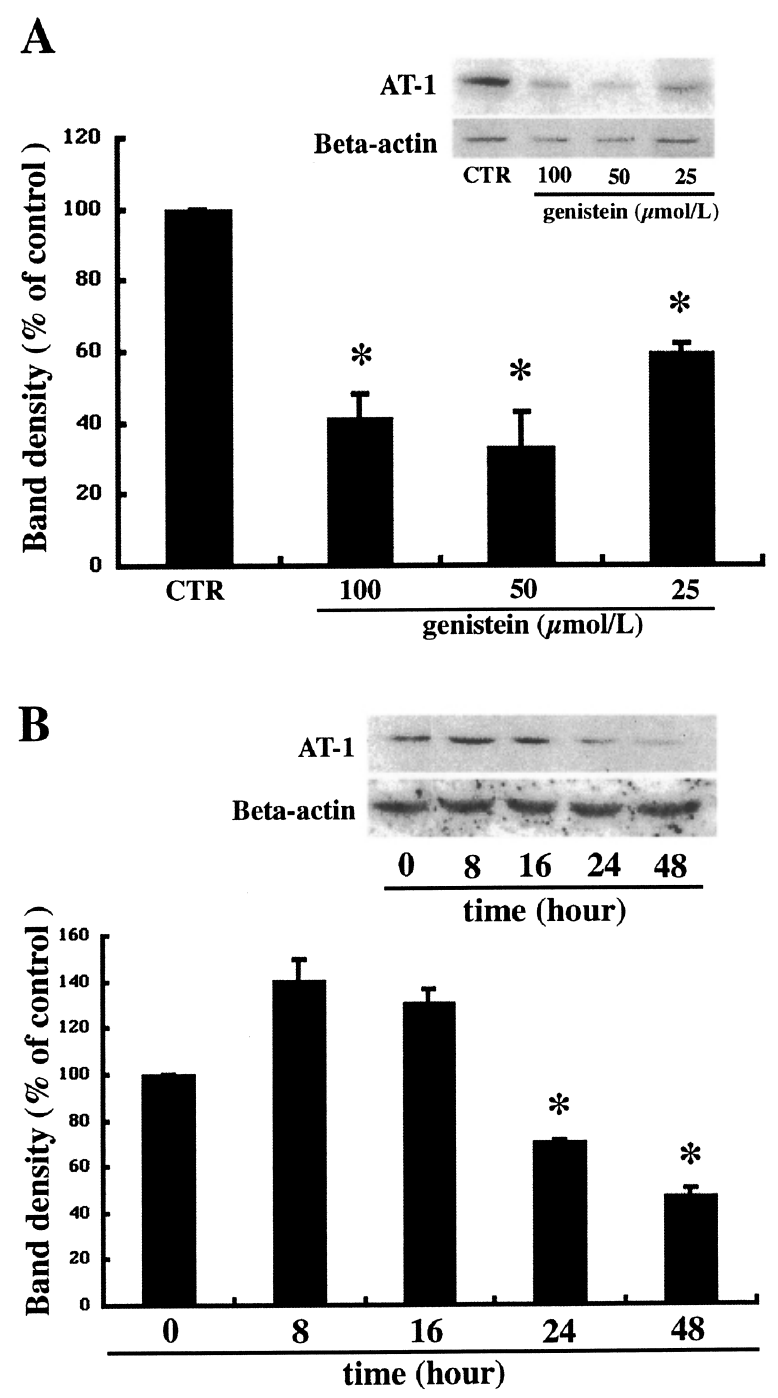

Fig. 3. Inhibitory effect of genistein on the expression of AT1 receptor in vascular endothelial cells from SHRSP by Western blotting assay. The cells were treated with genistein at 100, 50, or $25 \mu \mathrm{mol} / \mathrm{l}$ for $24 \mathrm{~h}(\mathrm{~A})$, or with genistein at $50 \mu \mathrm{mol} / \mathrm{l}$ for $8,16,24$, or $48 \mathrm{~h}(\mathrm{~B})$. The relative intensities compared with the control are shown as the mean \pm SEM of 3 independent experiments. ${ }^{*} \mathrm{p}<0.05$ vs. control.

control ( $n=3$ each; the inhibitions at 100 and $50 \mu \mathrm{mol} / 1$ genistein were significant $(p<0.05)$; Fig. $2 \mathrm{~A})$, and AT1 receptor expression to roughly $41.2 \pm 6.8 \%, 33.1 \pm 9.8 \%$, or $59.7 \pm 2.3 \%$ of the control ( $n=3$ and $p<0.05$ each; Fig. $3 \mathrm{~A}$ ). We next examined the time courses of the expressions of p22phox and AT1 receptor after treatment with genistein at $50 \mu \mathrm{mol} / \mathrm{l}$ (Figs. 2B and 3B). A reduction of $\mathrm{p} 22$ phox expression was detectable at 16 and $24 \mathrm{~h}$, and a reduction of AT1 receptor expression was detectable at 24 and $48 \mathrm{~h}$. Both the downregulation rates of p22phox and AT1 receptor expressions at $24 \mathrm{~h}$ were significantly lower than that of the control $(0 \mathrm{~h})$. The p22phox expressions at 16 and $24 \mathrm{~h}$ were about
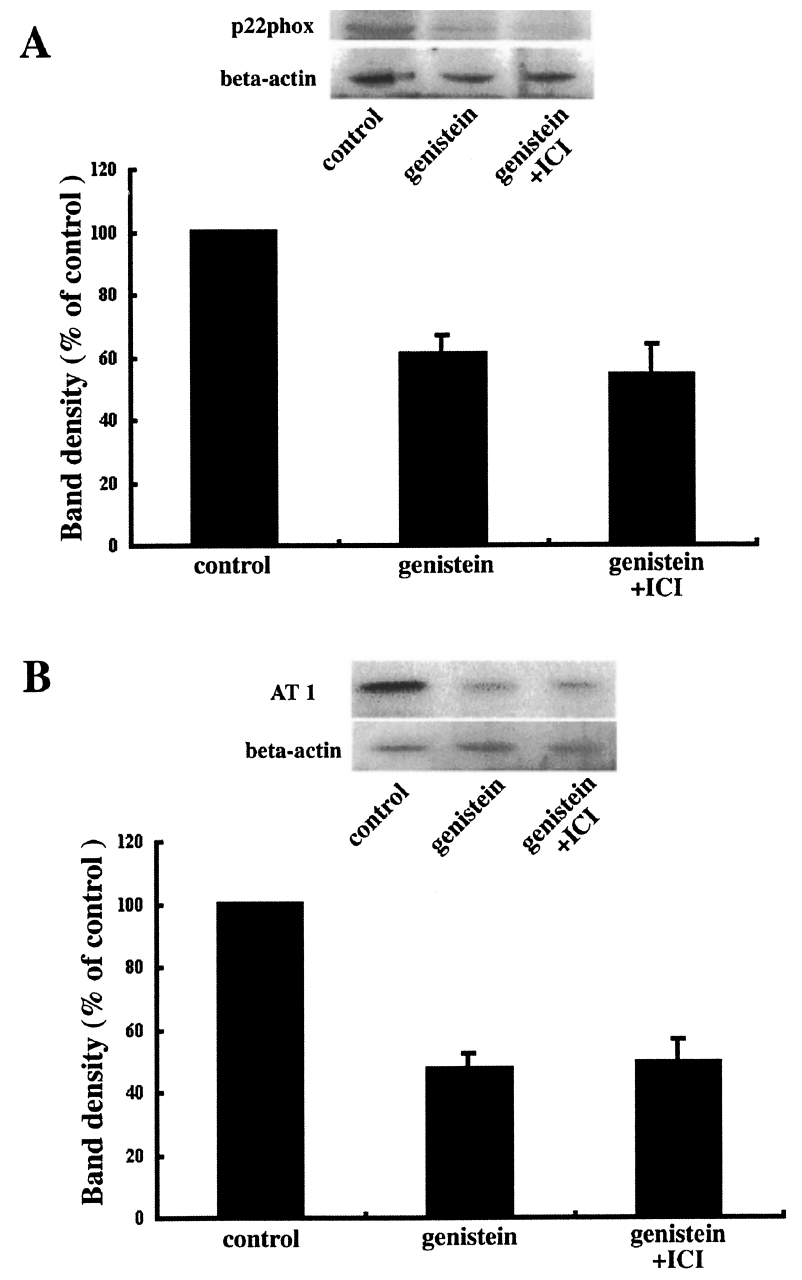

Fig. 4. The effect of ICI 182780 on the expressions of NADPH oxidase p22phox subunits and the AT1 receptor treated with genistein. Cells were incubated with genistein at $50 \mu \mathrm{mol} / \mathrm{l}$ for $24 \mathrm{~h}$ with or without ICI 182780 (50 $\mu \mathrm{mol} / \mathrm{l})$. The relative intensities compared with the control are shown as the mean \pm SEM of 3 independent experiments.

$59.38 \pm 19.65 \%$ and $50.43 \pm 18.36 \%$ of that at $0 \mathrm{~h}(n=3$ and $p<0.05$ each; Fig. 2B), while the AT1 receptor expressions at 24 and $48 \mathrm{~h}$ were approximately $70.82 \pm 0.63 \%$ and 47.08 $\pm 2.98 \%$ of that at $0 \mathrm{~h}(p<0.05$ and $n=3$ each; Fig. $3 \mathrm{~B})$.

PPARy, but Not the Estrogen Receptor, Mediated the Inhibitory Effect of Genistein on the Expressions of the p22phox NADPH Oxidase Subunit and AT1 Receptor

Genistein and other soy isoflavones are considered to be natural selective estrogen receptor modulators (SERMs) (31). For this reason, to investigate whether the estrogen receptor regulates the inhibitory effect of genistein on the expressions of the p22phox NADPH oxidase subunit and AT1 receptor, we selected ICI-182780, an estrogen receptor antagonist. 

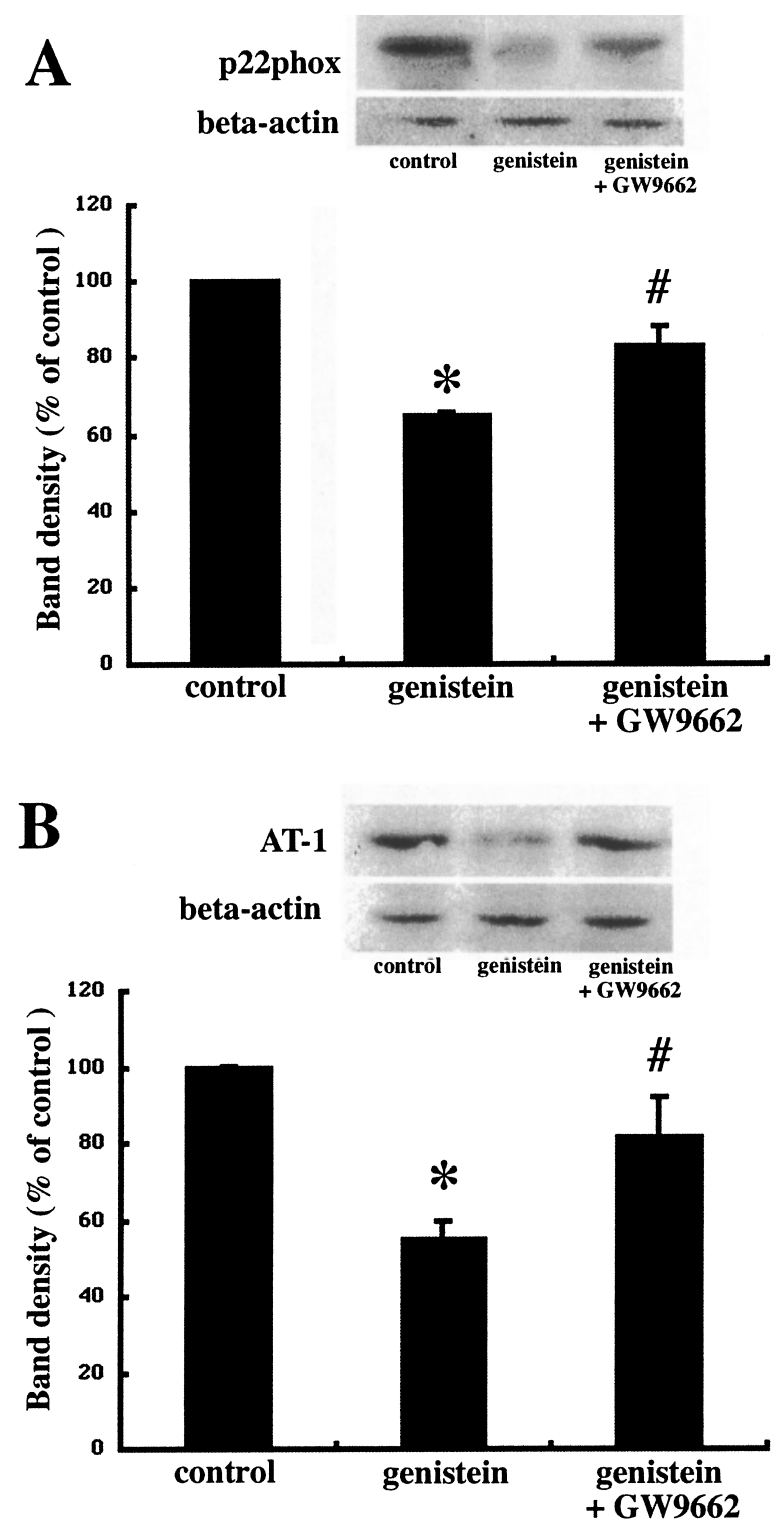

Fig. 5. The effect of GW9662 on the expressions of NADPH oxidase p22phox subunits and the AT1 receptor treated with genistein. Cells were incubated with genistein $(50 \mu \mathrm{mol} / \mathrm{l})$ for $24 \mathrm{~h}$ with or without $\mathrm{GW} 9662(50 \mu \mathrm{mol} / \mathrm{l})$. The relative intensities compared with the control are shown as the mean \pm SEM of 3 independent experiments. ${ }^{*} \mathrm{p}<0.05$ vs. control, ${ }^{\#} \mathrm{p}<0.05$ vs. genistein group.

However, when cells were pretreated with ICI-182780, an estrogen-receptor antagonist, at a concentration of $50 \mu \mathrm{mol} / 1$ for $30 \mathrm{~min}$ and then co-incubated with ICI-182780 and genistein for $24 \mathrm{~h}$, the inhibitory effect of genistein was not blocked (Fig. 4). Because the PPAR $\gamma$ regulates the expression of the p22phox NADPH oxidase subunit and AT1 receptor $(32,33)$, we wanted to investigate whether the inhibitory effect of genistein occurred through the activation of the $\operatorname{PPAR} \gamma$. The endothelial cells were pretreated with

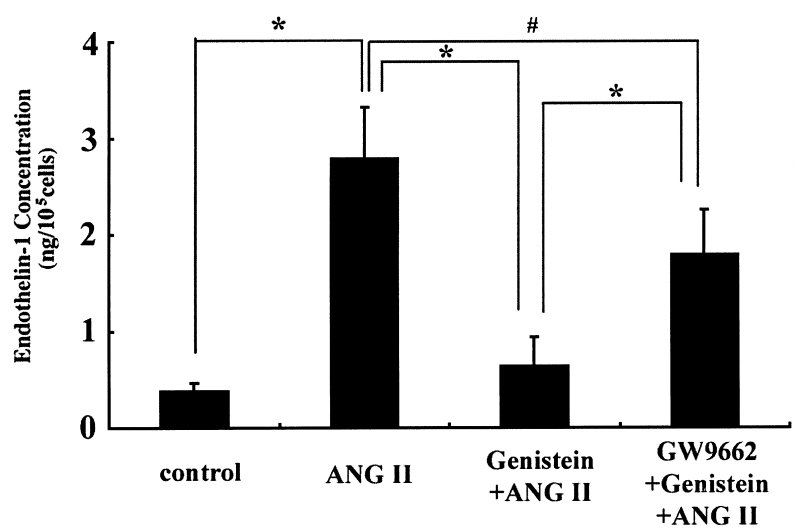

Fig. 6. Effects of genistein on endothelin-1 generation in angiotensin II-stimulated endothelial cells from SHRSP. Endothelial cells from SHRSP were incubated with or without genistein for 30 min prior to treatment with Ang II. In the experiment using GW9662, 5 umol/ GW9662 was added to cells for $30 \mathrm{~min}$ before genistein treatment. Then the cells were stimulated with Ang II $(1 \mu \mathrm{g} / \mathrm{ml})$ for $24 \mathrm{~h}$. The results are the mean \pm SEM of 5 independent wells. ${ }^{*} \mathrm{p}<0.01,{ }^{*} \mathrm{p}<0.05$ compared with the bars indicated.

GW9662 (34), a PPAR $\gamma$ antagonist, for 30 min prior to treatment with genistein, and the inhibitory effect of genistein was partially reversed by GW9662, as shown in Fig. 5. The band density of p22phox in Western blotting changed from $64.87 \pm 1.23 \%$ with genistein treatment to $82.82 \pm 5.35 \%$ with GW9662 plus genistein co-incubation; similarly, the

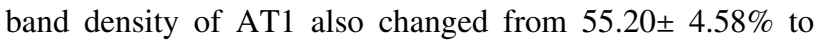
$82.06 \pm 9.91 \%$ of the control.

\section{Genistein Inhibited Ang II-Induced Endothelin-1}

It has been reported that Ang II and reactive oxygen species (ROS) induce endothelin-1 generation (35-37). As shown in Fig. 6, when endothelial cells from SHRSP were incubated with Ang II, the endothelin-1 generation was about 2.802 \pm $0.518 \mathrm{ng} / 10^{5}$ cells and significantly higher than that in the control $\left(0.386 \pm 0.085 \mathrm{ng} / 10^{5}\right.$ cells, $n=5$ each, $\left.p<0.01\right)$. To confirm the role of genistein in endothelin-1 secretion, the cells were pretreated with genistein for $30 \mathrm{~min}$. The Ang IIstimulated endothelin-1 generation showed an extraordinary reduction $\left(0.644 \pm 0.298 \mathrm{ng} / 10^{5}\right.$ cells; $p<0.01 v s$. Ang II). Furthermore, when cells were treated with GW9662 for 30 min prior to genistein, GW9662 partially blocked the inhibitory effect of genistein, and endothelin-1 generation was $1.804 \pm 0.45 \mathrm{ng} / 10^{5}$ cells $(p<0.05$ vs. Ang II; $p<0.01 v s$. genistein plus Ang II ). The results suggest that genistein inhibits the Ang II-induced endothelin-1 generation, and that GW9662, through the PPAR $\gamma$ pathway, partially but significantly blocks the inhibitory effect of genistein. 


\section{Discussion}

Genistein, one of nature's SERMs, strongly binds to the estrogen receptor subtype $\beta$ (17). Wanger and colleagues deduced that $17 \beta$-estradiol could inhibit the expressions of NADPH oxidase p22phox and gp91phox subunits (38). Moreover, estrogen has also been shown to exhibit a strong antioxidant potential in vivo in female spontaneously hypertensive rats (SHR) (39). This suggested that genistein as an SERM may possess antioxidant potential and may perhaps inhibit the expression of NADPH oxidase. In the present study, as shown in Fig. 1, genistein indirectly restricted $\mathrm{O}_{2}{ }^{-}$ formation and 3- $\mathrm{N}$-nitrotyrosine production in Ang II-stimulated SHRSP arterial endothelial cells, because rinsing after incubation with genistein removed the direct effect of genistein (Fig. 1A), and because genistein suppressed the expression of the NADPH oxidase p22phox subunit (Fig. 2). Other polyphenols, such as green or black tea polyphenols, also have similar effects of down-regulating $\mathrm{O}_{2}{ }^{-}$production and the expression of NADPH oxidase p22phox and p67phox subunits in bovine vascular endothelial cells (40). On the other hand, Ang II induces superoxide anion generation via the activation of NADPH oxidase in vascular endothelial cells (7). Therefore, the expression level of the AT1 receptor is an important factor for superoxide anion generation. For this reason, we also observed the effect of genistein on AT1 receptor expression. As shown in Fig. 3, genistein significantly suppressed AT1 receptor expression after treatment for 24 and $48 \mathrm{~h}$. These results resembled the observations of the Nickenig group that estrogen and the selective estrogen receptor modulator could induce the downregulation of AT1 receptor expression $(41,42)$. On the other hand, the transient rise in AT1 receptor expression after treatment with genistein for 8 and $16 \mathrm{~h}$ seems to be due to post-transcriptional feedback modulated by the direct antioxidative role of genistein as a tyrosine kinase inhibitor (43), since the tyrosine kinase inhibitor $\mathrm{pp} 2$ suppressed superoxide anion generation from NADPH oxidase (44), and since superoxide anion down regulated the stability of AT1 mRNA (45). Alternatively, the direct antioxidative effect of genistein may transiently increase the stability of AT1 mRNA and protein expression when cells are treated with genistein.

It is puzzling that ICI 182780, an estrogen receptor antagonist, could not completely obstruct the inhibitory effect of genistein on p22phox and AT1 receptor expressions (Fig. 4), suggesting that genistein exerts its inhibitory effect through an estrogen receptor-insensitive pathway. This estrogen receptor-insensitive phenomenon has also been observed in the reduction of post-injury neo-intima formation in a female rabbit aortic section after endothelial balloon denudation (46). The mechanisms of phytoestrogens include estrogenlike and antiestrogen effects (13). Recently, a group study indicated that estrogen can induce the production of a peroxisome proliferator-activated receptor (PPAR) ligand in
PPAR $\gamma$-expressing tissue $(47,48)$. The two PPAR $\gamma$ isoforms, PPAR $\gamma 1$ and PPAR $\gamma 2$, are expressed in distinct cells. $\operatorname{PPAR} \gamma 1$ seems to be ubiquitously expressed, whereas higher levels of PPAR $\gamma 2$ are expressed in adipose tissue. Moreover, two studies have indicated that genistein can act as a PPAR $\gamma$ agonist to regulate lipid metabolism $(25,26)$. Since PPAR $\gamma$ is also expressed in vascular endothelial cells (49, 50 ), we examined the role of PPAR $\gamma$ in the inhibitory effect of genistein on p22phox and AT1 receptor expressions. GW9662, a PPAR $\gamma$ antagonist, strongly blocked this inhibitory effect of genistein (Fig. 5), suggesting that PPAR $\gamma$ plays a role in the mediated signaling of genistein in regulating p22phox and AT1 receptor expressions. In the present study, however, Western blotting showed that the levels of PPAR $\gamma$ protein expression were not remarkably changed after treatment with $50 \mu \mathrm{mol} / \mathrm{l}$ genistein for 8,16 , or $24 \mathrm{~h}$ (data not shown). On the other hand, Dang et al. (26) indicated that at low concentrations $(\leq 1 \mu \mathrm{mol} / \mathrm{l})$, genistein acts like estrogen, while at high concentrations $(>1 \mu \mathrm{mol} / \mathrm{l})$, genistein acts as a ligand of PPAR $\gamma$. Moreover, Mezei et al. (25) reported that both of the soy isoflavones genistein and daidzein increased PPAR $\gamma$-directed gene expression 2-4 fold in RAW 264.7 cells. Interestingly, although the PPAR $\gamma$ receptors negatively regulate the activity of estrogen receptors and vice versa, both PPAR $\gamma$ and estrogen also decrease p22phox and AT1 receptor expressions in vascular endothelial and smooth muscle cells $(32,33,51,52)$. In addition, the neo-intimal formation of balloon-injured vessels, which is inhibited by estrogen but is not influenced by the pure synthetic estrogen receptor antagonist, ICI 182780, is also inhibited by troglitazone, a PPAR $\gamma$ activator (53). Our data suggested that the estrogen receptor-insensitive or anti-estrogen phenomena of estrogen and phytoestrogen may be involved in the role of PPAR $\gamma$ in addition to the effects of genistein or the tyrosine kinase inhibitor. On the other hand, Ang II and ROS can induce endothelin-1 generation (35-37). The present study (Fig. 6), as well as a previous report (54), indicated that genistein attenuated endothelin-1 production. In addition, this inhibitory effect of genistein was partially blocked by GW9662. Interestingly, PPAR $\gamma$ activators also inhibit thrombin-, insulin-, and oxidized low-density lipoprotein-induced endothelin-1 secretion in endothelial cells (55-57).

In summary, the present in vitro studies demonstrated that genistein attenuated the protein expression of the p22phox NADPH oxidase subunit and AT1 receptor in a concentration- and time-dependent manner in aortic endothelial cells from SHRSP, which showed that the inhibitory effect of genistein depends partly on the PPAR $\gamma$ signal pathway, since GW9662, a PPAR $\gamma$ antagonist, blocked to some degree this inhibitory effect of genistein. Next, pretreatment with genistein for $24 \mathrm{~h}$ also suppressed the Ang II-stimulated superoxide anion, nitrotyrosine, and endothelian-1 generation. Thus, genistein acting as a dietary antioxidant may have great benefit for the prevention of cardiovascular diseases such as hypertension and atherosclerosis. 


\section{References}

1. Barry-Lane PA, Patterson C, Merwe M, et al: p47 phox is required for atherosclerotic lesion progression in ApoE - / mice. J Clin Invest 2001; 108: 1513-1522.

2. Sorescu D, Weiss D, Lassegue B, et al: Superoxide production and expression of NOX family proteins in human atherosclerosis. Circulation 2002; 105: 1429-1435.

3. Azumi $\mathrm{H}$, Inoue $\mathrm{N}$, Takeshita $\mathrm{S}$, et al: Expression of NADH/NADPH oxidase p22(phox) in human coronary arteries. Circulation 1999; 100: 1494-1498.

4. Zalba G, Beaumont FJ, Jose GS, et al: Vascular NADH/ NADPH oxidase is involved in enhanced superoxide production in spontaneously hypertensive rats. Hypertension 2000; 35: 1055-1061.

5. Beswick RA, Dorrance AM, Leite R, Webb RC: NADH/ NADPH oxidase and enhanced superoxide production in the mineralocorticoid hypertensive rat. Hypertension 2001; 38: $1107-1111$.

6. Rey FE, Cifuentes ME, Kiarash A, Quinn MT, Pagano PJ: Novel competitive inhibitor of $\mathrm{NAD}(\mathrm{P}) \mathrm{H}$ oxidase assembly attenuates vascular $\mathrm{O}_{2}{ }^{-}$and systolic blood pressure in mice. Circ Res 2001; 89: 408-414.

7. Zhang H, Schmeisser A, Garlichs CD, et al: Angiotensin IIinduced superoxide anion generation in human vascular endothelial cells: role of membrane-bound NADH-/NADPHoxidases. Cardiovasc Res 1999; 44: 215-222.

8. Wattanapitayakul SK, Weinstein DM, Holycross BJ, Bauer JA: Endothelial dysfunction and peroxynitrite formation are early events in angiotensin-induced cardiovascular disorder. FASEB J 2000; 14: 271-278.

9. Ma X-L, Gao F, Nelson AH, et al: Oxidative inactivation of nitric oxide and endothelial dysfunction in stroke-prone spontaneous hypertensive rats. J Pharmacol Exp Ther 2001; 298: 879-885.

10. Sohn HY, Raff U, Hoffmann A, et al: Differential role of angiotensin II receptor subtypes on endothelial superoxide formation. Br J Pharmacol 2000; 131: 667-672.

11. Zhang C, Hein TW, Wang W, Kuo L: Divergent roles of angiotensin II AT1 and AT2 receptors in modulating coronary microvascular function. Circ Res 2003; 92: 322-329.

12. Chabrashvili T, Kitiyakara C, Blau J, et al: Effects of ANG II type 1 and 2 receptors on oxidative stress, renal NADPH oxidase, and SOD expression. Am J Physiol Regul Integr Comp Physiol 2003; 285: R117-R124.

13. Kurzer MS, Xu X: Dietary phytoestrogens. Annu Rev Nutr 1997; 17: 353-381.

14. Setchell KDR, Cassidy A: Dietary isoflavones: biological effects and relevance to human health. J Nutr 1999; 129: 758S-767S.

15. Lichtenstein AH: Soy protein, isoflavones and cardiovascular disease risk. J Nutr 1998; 128: 1589-1592.

16. Clarkson TB: Soy, soy phytoestrogens and cardiovascular disease. J Nutr 2002; 132: 566S-569S.

17. Kuiper GGJM, Lemmen JG, Carlsson B, et al: Interaction of estrogenic chemicals and phytoestrogens with estrogen receptor $\beta$. Endocrinology 1998; 139: 4252-4263.

18. An J, Tzagarakis-Foster C, Scharschmidt TC, Lomri N, Leitman DC: Estrogen receptor $\beta$-selective transcriptional activity and recruitment of coregulators by phytoestrogens. J Biol Chem 2001; 276: 17808-17814.

19. Ruiz-Larrea MB, Mohan AR, Paganga G, Miller NJ, Bolwell GP, RiceEvans CA: Antioxidant activity of phytoestrogenic iosflavones. Free Radic Res 1997; 26: 63-70.

20. Wei H, Bowen R, Cai Q, Barnes S, Wang Y: Antioxidant and antiproliferative effect of the soybeen isoflavone genistein. Proc Soc Exp Biol Med 1995; 208: 124-130.

21. Djuric Z, Chen G, Doerge DR, Heilbrum LK, Kucuk O: Effect of soy isoflavone supplementation on markers of oxidative stress in men and women. Cancer Lett 2001; 172: $1-6$.

22. Sierens J, Hartley JA, Campbell MJ, Leathem AJC, Woodside JV: Effect of phytoestrogen and antioxidants supplementation on oxidative DNA damage assessed using the comet assay. Mutat Res 2001; 485: 169-176.

23. Mizutani K, Ikeda K, Nishikata T, Yamori Y: Phytoestrogens attenuate oxidative DNA damage in vascular smooth muscle cells from stroke-prone spontaneously hypertensive rats. J Hypertens 2000; 18: 1833-1840.

24. Rohrdanz E, Ohler S, Tran-Thi Q-H, Kahl R: The phytoestrogen daidzein affects the antioxidant enzyme system of rat hepatoma H411E cells. J Nutr 2002; 132: 370-375.

25. Mezei O, Banz WJ, Steger RW, Peluso MR, Winters TA, Shay N: Soy isoflavones exert antidiabetic and hypolipidemic effects through the PPAR pathways in obese Zucker rats and murine RAW 264.7 cells. J Nutr 2003; 133: 12381243.

26. Dang ZC, Audinot V, Papapoulos SE, Boutin JA, Lowik CWGM: PPAR $\gamma$ as a molecular target for the soy phytoestrogen genistein. J Biol Chem 2003; 278: 962-967.

27. McGuire PG, Orkin RW: Isolation of rat aortic endothelial cells by primary explant techniques and their phenotypic modulation by defined substrata. Lab Invest 1987; 57: 94105.

28. Xu JW, Morita I, Murota S: Role of SERCA2b in mobilization of nuclear $\mathrm{Ca}^{2+}$ in HeLa cells. J Med Dent Sci 2001; 48: $51-59$.

29. Suh YA, Arnold RS, Lassegue B, et al: Cell transformation by the superoxide-generating oxidase Mox1. Nature 1999; 401: 79-81.

30. Wang HD, Pagano PJ, Du Y, et al: Superoxide anion from the adventitia of the rat thoracic aorta inactivates nitric oxide. Circ Res 1998; 82: 810-818.

31. Setchell KDR: Soy isoflavones-benefits and risks from nature's selective estrogen receptor modulators (SERMs). $J$ Am Coll Nutr 2001; 20: 354S-362S.

32. Inoue I, Goto S, Matsunaga T, et al: The ligands/activators for peroxisome proliferator-activated receptor $\alpha(\operatorname{PPAR} \alpha)$ and PPAR $\gamma$ increase $\mathrm{Cu}^{2+}, \mathrm{Zn}^{2+}$-superoxide dismutase and decrease $\mathrm{p} 22$ phox message expressions in primary endothelial cells. Metabolism 2001; 50: 3-11.

33. Takeda K, Ichiki T, Tokunou T, et al: Peroxisome proliferator-activated receptor $\gamma$ activators downregulate angiotensin II type 1 receptor in vascular smooth muscle cells. Circulation 2000; 102: 1834-1839.

34. Huang JT, Welch JS, Ricote M, et al: Interleukin-4-dependent production of PPAR- $\gamma$ ligands in macrophages by 12/15-lipoxygenase. Nature 1999; 400: 378-382.

35. Kahler J, Ewert A, Weckmuller J, et al: Oxidative stress in- 
creases endothelin-1 synthesis in human coronary artery smooth muscle cells. J Cardiovasc Pharmacol 2001; 38: 49-57.

36. Imai $\mathrm{T}$, Hirata $\mathrm{Y}$, Emori $\mathrm{T}$, Yanagisawa $\mathrm{M}$, Masaki $\mathrm{T}$, Marumo F: Induction of endothelin-1 gene by angiotensin and vasopressin in endothelial cells. Hypertension 1992; 19: $753-757$.

37. Chua BH, Chua CC, Diglio CA, Siu BB: Regulation of endothelin-1 mRNA by angiotensin II in rat heart endothelial cells. Biochim Biophys Acta 1993; 1178: 201-206.

38. Wanger AH, Schroeter MR, Hecker M: $17 \beta$-estradiol inhibition of NADPH oxidase expression in human endothelial cells. FASEB J 2001; 15: 2121-2130.

39. Dantas APV, Tostes RCA, Fortes ZB, Costa SG, Nigro N, Carvalho MHC: In vivo evidence for antioxidant potential of estrogen in microvessels of female spontaneously hypertentive rats. Hypertension 2002; 39: 405-411.

40. Ying CJ, Xu JW, Ikeda K, Takahashi K, Nara Y, Yamori $\mathrm{Y}$ : Tea polyphenols regulate nicotinamide adenine dinucleotide phosphate oxidase subunit expression and ameliorate angiotensin II-induced hyperpermeability in endothelial cells. Hypertens Res 2003; 26: 823-828.

41. Nickenig G, Baumer AT, Grohe C, et al: Estrogen modulates AT1 receptor gene expression in vitro and in vivo. Circulation 1998; 97: 2197-2201.

42. Baumer AT, Wassmann S, Ahlbory K, et al: Reduction of oxidative stress and AT1 receptor expression by the selective oestrogen receptor modulator idoxifene. Br J Pharmacol 2001; 134:579-584.

43. Akiyama T, Ishida J, Nakagawa S, et al: Genistein, a specific inhibitor of tyrosine-specific protein kinases. $J$ Biol Chem 1987; 262: 5592-5595.

44. Touyz RM, Yao G, Schiffrin EL: c-Src induces phosphorylation and translocation of p47phox: role in superoxide generation by angiotensin II in human vascular smooth muscle cells. Arterioscler Thromb Vasc Biol 2003; 23: 981-987.

45. Nickenig G, Strehlow K, Baumer AT, et al: Negative feedback regulation of reactive oxygen species on AT1 receptor gene expression. Br J Pharmacol 2000; 131: 795-803.

46. Finking G, Lenz C, Schochat T, Hanke H: Reduction of post injury neointima formation due to $17 \beta$-estradiol and phytoestrogen treatment is not influenced by the pure synthetic estrogen receptor antagonist ICI 182,780 in vitro. BMC Cardiovasc Dis 2002; 2: 13. Open accessed at: http://www.biomedcentral.com/1471-2261/2/13

47. Ma H, Sprecher HW, Kolattukudy PE: Estrogen-induced production of a peroxisome proliferator-activated receptor
(PPAR) ligand in a PPAR $\gamma$-expressing tissue. J Biol Chem 1998; 273: 30131-30138.

48. Ma H, Tam QT, Kolattukudy PE: Peroxisome proliferatoractivated receptor $\gamma 1$ (PPAR- $\gamma 1$ ) as a major PPAR in a tissue in which estrogen induces peroxisome proliferation. FEBS Lett 1998; 434: 394-400.

49. Jackson SM, Parhami F, Xi XP, et al: Peroxisome proliferator-activated receptor activators target human endothelial cells to inhibit leukocyte-endothelial cell interaction. Arterioscler Thromb Vasc Biol 1999; 19: 2094-2104.

50. Delerive P, Martin-Nizard F, Chinetti G, et al: Peroxisome proliferator-activated receptor activators inhibit thrombininduced endothelin-1 production in human vascular endothelial cells by inhibiting the activator protein-1 signaling pathway. Circ Res 1999; 85: 394-402.

51. Sugawara A, Takeuchi K, Uruno A, et al: Transcriptional suppression of type 1 angiotensin II receptor gene expression by peroxisome proliferator-activated receptor- $\gamma$ in vascular smooth muscle cells. Endocrinology 2001; 142: 3125-3134.

52. Sugawara A, Takeuchi K, Uruno A, et al: Differential effects among thiazolidinediones on the transcription of thromboxane receptor and angiotensin II type 1 receptor genes. Hypertens Res 2001; 24: 229-233.

53. Law RE, Meehan WP, Xi XP, et al: Troglitazone inhibits vascular smooth muscle cell growth and intimal hyperplasia. J Clin Invest 1996; 98: 1897-1905.

54. Squadrito F, Altavilla D, Morabito N, et al: The effect of the phytoestrogen genistein on plasma nitric oxide concentrations, endothelin-1 levels and endothelium dependent vasodilation in postmenopausal women. Atherosclerosis 2002; 163: 339-347.

55. Delerive P, Martin-Nizard F, Chinetti G, et al: Peroxisome proliferator-activated receptor activators inhibit thrombininduced endothelin-1 production in human vascular endothelial cells by inhibiting the activator protein-1 signaling pathway. Circ Res 1999; 85: 394-402.

56. Satoh H, Tsukamoto K, Hashimoto Y, et al: Thiazolidinediones suppress endothelin-1 secretion from bovine vascular endothelial cells: a new possible role of PPAR $\gamma$ on vascular endothelial function. Biochem Biophys Res Commun 1999; 254: 757-763.

57. Martin-Nizard F, Furman C, Delerive P, et al: Peroxisome proliferator-activated receptor activators inhibit oxidized low-density lipoprotein-induced endothelin-1 secretion in endothelial cells. J Cardiovasc Pharmacol 2002; 40: 822831 . 